\title{
Mission Institution
}

Ronald Small

$\mathrm{T}$ hank you for giving me the opportunity to share my thoughts and experiences while being incarcerated in the Canadian federal penitentiary system and declared as a 'dangerous offender'. I served a lot of years at Mountain Institution and finally I earned my way to Ferndale Minimum Institution. I was at Ferndale Minimum for nearly five years, until 1 May 2008. I was shipped to a higher security - Mission Medium - when all 'dangerous offenders' who were in minimums across Canada to be placed in higher security. Staff used creative writing to justify this and as a result there was ten of us from Ferndale that were removed. The only problem I had at Ferndale was that I tested positive on a urinalysis test, which was the result of my taking a dentist prescribed Tylenol 3. I served several days in segregation for that and became the victim of creative writing so this punishment could be justified. The fact is, I was punished for something I should not have been punished for.

While I was at Mission Institution from 2008 to 2015 life became pure hell. In a span of two years, I had approximately eighteen institutional parole officers (IPO). Some were correctional officers in acting positions as parole officers. I even had a clerk acting as one. In 2015, the Parole Board granted me day parole. Unfortunately, I breached my conditions in 2016 and was placed at Mountain Institution. In this document, I make reference to The Standards of Professional Conduct in the Correctional Service of Canada Declaration, hereafter referred to as the Declaration. Enclosed you will find ten items I believe should seriously be looked into.

\section{INSTITUTIONAL PAROLE OFFICERS}

IPOs must be held accountable for their actions and inactions. These people signed the Declaration agreeing to undertake and maintain, in the course of their employment, the standards of professionalism and integrity that are therein set forth. The last IPO I had at Mission Medium Institution routinely put false and misleading entries in my file. I told him several times this was illegal. His response was that he was exempt from the law and could do whatever he wanted, and there was nothing I could do about that. On one occasion, he laughed at me and told me to file a complaint. I obliged and became a victim of abuse from upper management. I also confronted him in early 2015, telling him he was 
in breach of many of the conditions in the Declaration and also that I felt that he was 'sluffing' me off. He looked at me, laughed and agreed to what I said, then stated, "so why don't you take me to court?" This is just a sample of what I had to deal with on the caseload of one IPO. Had this person been working in the private sector he would have been fired. I believe a study of IPOs should be looked into as I have witnessed many problems they have caused me and many of my fellow prisoners. These people are supposed to be role models for us. If we followed their current lead Canadian society would be worse off.

\section{ACCOUNTABILITY}

I believe case management should be held accountable for their actions and inactions. Upper management is also included in this to the extent that these people go through the process of covering up for themselves and their coworkers, which is getting really bad. Saying, "Sorry, I made a mistake and I will correct it", is non-existent. The amount of time and taxpayer money that wasted on cover-ups is ridiculous. If a lot of these people were held accountable to the Declaration, they would be unemployed.

\section{FOOD}

The quality of the food we are given has really gone downhill. This budget saving project has turned out to be a failure. I have witnessed the kitchen staff hanging their heads in shame because of what they are forced to serve us. You will find that the waste of food being thrown out is extremely high, which converts to wasted taxpayer money.

\section{PRISONER PAY}

Our pay, along with the implications of paying additional room and board, has had a very dangerous and negative effect. Most prisoners do not have any money for themselves and with what little money we do get, it has forced an increase in sub-culture activities and also a financial burden on prisoners' families. What I see happening now is prisoners' planning their next score because they have no money upon release. I would suggest that Prime Minister Harper's punishment agenda, which still has effects today, is 
putting public safety more at risk by putting so many prisoners in a situation where they are forced to fall back on their bad behaviours.

\section{CORCAN INCENTIVE PAY}

When CORCAN incentive pay was taken away, I think it was a big mistake. This not only taught good work habits, but in many cases prisoners were able to financially help their families and loved ones. Why take this away from us if our families and the communities we return to are the primary beneficiaries?

\section{TELEPHONE SYSTEM}

This telephone system is a very expensive necessity, which a lot of prisoners cannot afford. Considering the little we get after additional room and board is deducted, we have very little left to cover the costs of communicating with our families and loved ones, especially if long distance phone calls are required. This has only limited communication with family, loved ones and support people, causing a financial burden on all.

\section{PRISONER PURCHASING}

Restricting prisoner purchases to a centralized catalogue system run by one company is a monopoly that few 'free market' proponents would ever tolerate. After additional room and board is deducted from our pay, we have very little money left to purchase items with. With what little money we make, we are now forced to buy products with inflated prices, price gouging, from a monopoly that is allowed to function without any real oversight. For example, London Drugs sells RCA 19-inch television for around $\$ 120$ or less. We are forced to buy the same television from the CSC contracted vendor/catalogue/warehouse for well over \$200. This is just one problematic example of many.

\section{GRIEVANCES}

This grievance and complaint system is completely broken, which the Correctional Investigator and the courts have routinely observed. This is 
demonstrated in the Spiedel versus CSC case. In this case, a self-represented prisoner who was serving a life-sentence in British Columbia challenged the efficacy of CSC's internal grievance procedure and was able to establish that the organization "failed to provide a substantive response to his grievances in a number of cases". One such grievance took 242 days to even receive a single response from $\mathrm{CSC}$, who are legislatively obligated to respond within 15 working days. ${ }^{1}$ This system has been purposely abused by CSC, which also solidifies the many breaches of the Declaration by so many CSC personnel. The Declaration states that CSC staff are supposed to be role models for us. I think you would have to agree, CSC has really failed in this department.

\section{WAREHOUSING}

Warehousing prisoners at higher security is now common, particularly for those with lengthy sentences. I am a prime example of this practice. I was at Ferndale Minimum for about nearly five years, and then was shipped to higher security and punished for something I did not do. I was warehoused at Mission Medium Institution for eight years. In August 2015, the parole board told my IPO that he had failed to do his job and I was granted day parole. On many occasions, myself and many fellow prisoners have been told we "haven't done enough time yet". I have asked for the policy on this issue and got nothing but anger and abuse as a response.

\section{HEALTH CARE}

I have been victimized by the health care department like so many other prisoners. They are accountable to no one. I arrived here at Mountain Institution in 2016. I have arthritis and was given medication for that until it was cut down by a third by some doctor I did not know. It took about 45 days to see a doctor and get my medication back. It was the same doctor who took my medication away previously. While I was on parole, a streetdoctor had me x-rayed and informed me I had advanced deterioration of my left hip. I put in to see the doctor here for help with the pain I have. This doctor looked at me, re-diagnosed me and gave me a needle in my left hip. I asked if this would help and he said probably not. Later that year, I asked to see the optometrist to get prescription glasses I needed. It took 
ten months for this to happen. I have filed a complaint with the College of Physicians and Surgeons, but I do not expect much help. I have found, like many other fellow prisoners, that to receive help we need to take it outside of the institution. I personally feel the abuse we get from health care should be exposed and those people involved should be held accountable, even if just to the letter of the Declaration.

\section{CONCLUSION}

I could write more, but I believe I have contributed enough to help inform future reforms to CSC. I am writing this document knowing that I have a parole hearing coming soon. I have been advised my freedom could be jeopardized by my writing this document to you. I am an elderly man and will not be victimized by fear and intimidation, and bullying that is commonly used by CSC personnel. I really hope what I have written will be useful in helping to shape the future of federal imprisonment in Canada.

\section{ENDNOTES}

1 Spidel v. Canada (Attorney General). 2012 FC 140. 